\title{
Summary of Toxicology Studies with Butachlor
}

\author{
Alan G.E. WILSON and Ayako S. TAKeI \\ Monsanto Company
}

(Accepted November 20, 1999)

\section{DESCRIPTION OF THE TEST CHEMICAL}

Butachlor was developed by Monsanto Company (USA) and introduced in 1968 for the pre-emergence control of undesirable grasses and broadleaf weeds in transplanted, direct seeded rice and barley fields. Butachlor was first introduced in Japan in 1973 and has been used for the control of grass weeds and broadleaf weeds in transplanted rice paddies.

Butachlor is a member of the chloroacetanilide class of chemistry and is the herbicidal active ingredient in MACHETE ${ }^{\circledR}$ EC. This report summarizes the results of laboratory toxicology studies conducted with butachlor. The physical and chemical properties of butachlor are given below:

Common name: Butachlor

Chemical name: 2-chloro-2',6'-diethyl-N-(butoxymethyl)acetanilide

Chemical structure:

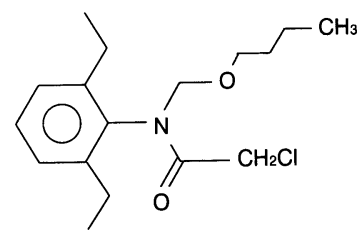

Molecular formula: $\mathrm{C}_{17} \mathrm{H}_{26} \mathrm{NO}_{2} \mathrm{Cl}$

Molecular weight: 311.9

Physical state: clear amber liquid @ room temperature Melting point: $4-5{ }^{\circ} \mathrm{C}$

Vapor pressure: $1.8 \times 10^{-6} \mathrm{~mm} \mathrm{Hg} @ 25^{\circ} \mathrm{C}$

Decomposition temperature: $156^{\circ} \mathrm{C}$

Water solubility: $20 \mathrm{ppm} @ 25^{\circ} \mathrm{C}$

Butachlor is miscible with alcohol, ether, acetone and other organic solvents.

\section{ACUTE TOXICITY STUDIES}

\section{Butachlor Technical Material}

The results of acute toxicity studies with butachlor are shown in Table 1. In these tests, no distinctive signs of toxicity were observed following exposure via the oral, dermal and inhalation routes.

\section{Machete ${ }^{\circledR}$ EC Herbicide}

Machete ${ }^{\circledR}$ EC Herbicide is an organic solvent-based liquid formulation containing approximately $32 \%$ or $60 \%$ butachlor. The results of acute toxicity studies with the formulated product are shown in Table 2 . In these tests, no distinctive signs of toxicity were observed following exposure via the oral, dermal and inhalation routes.

\section{IRRITATION STUDIES}

\section{Primary Dermal Irritation}

Butachlor was applied topically to the shaven backs of 6 New Zealand white rabbits (2 sites per rabbit). Continuous 24 hrs exposure resulted in slight erythema and edema. The primary irritation index was calculated to be 3.5 on a scale of 8.0. Butachlor was moderately irritating to the rabbit skin. (Bio/dynamics Inc., 1979)

\section{Primary Ocular Irritation}

Butachlor was placed into the conjunctival sac of the right eye of 6 New Zealand white rabbits. The contralateral eye served as the control. Only a slight degree of irritation of the conjunctivae was seen in 2 of 6 rabbits. No effect on the cornea or iris was observed. Eyes regained their normal appearance by 3 days after exposure. Butachlor was slightly irritating to the eyes of rabbits.

(Bio/dynamics Inc., 1979)

\section{DERMAL SENSITIZATION STUDIES}

The potential of butachlor to induce dermal hypersensitivity was evaluated in a modified Buehler assay. ${ }^{1,2}$ Induction involved topical exposure of 5 male and female Hartley albino guinea-pigs each, to undiluted butachlor for 6 hours, 3 days per week for 3 weeks. Treated and naive guinea-pigs ( 3 per sex) were challenged with $50 \%$ butachlor in acetone 2 weeks after the last induction dose. Butachlor produced slight irritation following initial application; moderate irritation was observed after the second application; and moderate to severe erythema with edema was observed in all animals after the third application. On challenge, 5 out of 10 animals exhibited a positive skin response. After the second challenge which was conducted to confirm the response, all animals 
Table 1 Results of acute toxicity tests with butachlor.

\begin{tabular}{|c|c|c|c|}
\hline $\begin{array}{l}\text { Route of } \\
\text { administration }\end{array}$ & Species & Sex & Median lethal dose \\
\hline \multirow[t]{2}{*}{ Oral } & Rat $^{\text {a) }}$ & $\begin{array}{l}0^{7} \\
\text { o }\end{array}$ & $\begin{array}{l}2620 \mathrm{mg} / \mathrm{kg} \\
3050 \mathrm{mg} / \mathrm{kg}\end{array}$ \\
\hline & Mouse $^{b)}$ & $\begin{array}{l}\text { o } \\
\text { ㅇ }\end{array}$ & $\begin{array}{l}4140 \mathrm{mg} / \mathrm{kg} \\
5030 \mathrm{mg} / \mathrm{kg}\end{array}$ \\
\hline Dermal & Rabbit ${ }^{c)}$ & 이우 & $13,000 \mathrm{mg} / \mathrm{kg}$ \\
\hline Inhalation & Rat $^{\text {d) }}$ & 짐우 & $>5.3 \mathrm{mg} / \mathrm{l}$ \\
\hline
\end{tabular}

a) Institute of Environmental Toxicology, 1980. b) Institute of Environmental Toxicology, 1976. c) Bio/dynamics Inc., 1979. d) Monsanto Safety Evaluation-Newstead, 1998.

Table 2 Results of acute toxicity tests with Machete $^{\circledR}$ EC herbicide.

\begin{tabular}{|c|c|c|c|}
\hline $\begin{array}{l}\text { Route of } \\
\text { administration }\end{array}$ & Species & Sex & Median lethal dose \\
\hline Oral & $\begin{array}{l}\text { Rat }^{\mathrm{a})} \\
\text { Mouse }^{\mathrm{b})}\end{array}$ & $\begin{array}{l}0^{\pi} \text { 우 } \\
0^{7} \\
\text { 우 }\end{array}$ & $\begin{array}{l}2800 \mathrm{mg} / \mathrm{kg} \\
4604 \mathrm{mg} / \mathrm{kg} \\
5675 \mathrm{mg} / \mathrm{kg}\end{array}$ \\
\hline Dermal & Rabbit ${ }^{\text {a) }}$ & 주우 & $>2000 \mathrm{mg} / \mathrm{kg}$ \\
\hline Inhalation & $\mathrm{Rat}^{\mathrm{c})}$ & 주우 & $1.63 \mathrm{mg} / \mathrm{l}$ \\
\hline
\end{tabular}

a) Bio/dynamics Inc., 1979: Study conducted with butachlor 60\% EC. b) Bozo Research Center, Inc., 1993: Study conducted with butachlor 32\% EC. c) Bio/dynamics Inc., 1981: Study conducted with butachlor $60 \%$ EC.

exhibited a positive skin response. Butachlor is considered to be a dermal sensitizer in the guinea-pig.

(Bio/dynamics Inc., 1983)

\section{SUBCHRONIC TOXICITY STUDIES}

\section{Ninety-Day Feeding Study in Rats}

Butachlor was administered in the diet to groups of 12 male and female Fischer-344 (F-344) rats each, at concentrations of $0,300,1000,3000$ and 5000 ppm for 90 days. The animals were housed individually in stainless steel cages. Decreased body weight gain was observed in both sexes at the $1000 \mathrm{ppm}$ dietary level and above. Mild anemia was observed in both sexes at $5000 \mathrm{ppm}$ and in females at $3000 \mathrm{ppm}$. Evidence of liver toxicity (e.g. increased $\gamma$-glutamyl transpeptidase, alanine aminotransferase, cholesterol and liver weights as well as diffuse hepatocellular swelling) was observed in males only at the $1000 \mathrm{ppm}$ dietary level and above, and in females only at the $3000 \mathrm{ppm}$ dietary level and above. Early signs of glomerulonephropathy were apparent in males at the $1000 \mathrm{ppm}$ dietary level and above. Epithelial hyperplasia of the urinary bladder was apparent in males at the $5000 \mathrm{ppm}$ and in females at the $1000 \mathrm{ppm}$ dietary level and above. The No Observed Effect Level (NOEL) was considered to be $300 \mathrm{ppm}(17.5 \mathrm{mg} / \mathrm{kg} /$ day for males and $19.0 \mathrm{mg} / \mathrm{kg} /$ day for females).

(Institute of Environmental Toxicology, 1987)

\section{Ninety-Day Feeding Study in Wistar Rats}

Butachlor was administered in the diet to groups of 15 male and female Wistar Imamichi rats each, at concentrations of $0,500,1000,2500,5000,10,000,20,000$ and 40,000 ppm for 90 days. Reduced body weight gains were observed in males and females at the $5000 \mathrm{ppm}$ dietary level and above. Statistically significant decreases in feed consumption were found in male and female rats at $10,000 \mathrm{ppm}$. There was mortality at the $10,000 \mathrm{ppm}$ dietary level or above but not at the $5000 \mathrm{ppm}$ or lower. At the dietary levels of $2500 \mathrm{ppm}$ and higher, hemoglobin concentration, hematocrit value and RBC were decreased, suggesting possible anemia.

Decreased RBC CHE values in males at the $2500 \mathrm{ppm}$ dietary level and above, and females at 10,000 ppm were noted. Plasma CHE was decreased in males at 10,000 ppm but in females no decrease was found for plasma or brain CHE values.

Statistically significant differences were found in brain, pituitary, ovary, uterus and heart weights, but there were no histopathological changes, and therefore, these organ weight changes were not considered biologically significant. Decreased kidney weights were observed in females at the $5000 \mathrm{ppm}$ dietary level and in males at the $10,000 \mathrm{ppm}$ dietary level. Spleen weight was reduced in both males and females at dietary levels of $2500 \mathrm{ppm}$ and higher. Histopathologically, dose-related changes were found in the spleen, kidney and liver of animals at dietary levels of $2500 \mathrm{ppm}$ and higher. Atrophy was observed in the ovaries and testes at $40,000 \mathrm{ppm}$; these findings may have been related to malnutrition at this very high dose level. The NOEL for this study was considered to be $1000 \mathrm{ppm}(68.0 \mathrm{mg} / \mathrm{kg} /$ day for males and $72.2 \mathrm{mg} / \mathrm{kg} /$ day for females).

(Nihon University of Veterinary Medicine and Zootechnology, 1971)

\section{Ninety-Day Feeding Study in Sprague-Dawley Rats}

Butachlor was administered in the diet to groups of 20 male and female Sprague-Dawley (S-D) rats each, at concentrations of $0,1000,5000,7500$ and $15,000 \mathrm{ppm}$. Animals were housed individually in stainless steel cages. Physical signs of toxicity (hair loss and emaciation) and mortality (one female) were noted only at the $15,000 \mathrm{ppm}$ dietary level. These animals also exhibited markedly decreased body weights, decreased food consumption, changes in hematology, serum biochemistry and urinalysis parameters, liver and thyroid organ weight changes, histopathological evidence of liver damage, and gross and histopathological evidence of kidney damage. Most of these effects were also noted at the 5000 and 7500 ppm dietary levels. The animals at the $1000 \mathrm{ppm}$ dietary level exhibited increased liver and thyroid weights. Because of the lack of corresponding histopathological effects, these organ weight changes (liver and thyroid) 
were considered equivocal evidence of toxicity and the NOEL of this study was therefore determined as 1000 $\mathrm{ppm}(67.9 \mathrm{mg} / \mathrm{kg} / \mathrm{day}$ for males and $97.7 \mathrm{mg} / \mathrm{kg} / \mathrm{day}$ for females).

(Bio/dynamics, Inc./Institute of Environmental Toxicology, 1980)

\section{Ninety-Day Feeding Study in DDY Mice}

Butachlor was administered in the diet to groups of 78 male and female DDY mice each, at concentrations of 0,500 (females only), 1000, 2500, 5000, 10,000 and $20,000 \mathrm{ppm}$. No mortality was found in mice at the $5000 \mathrm{ppm}$ dietary level or lower. At the $10,000 \mathrm{ppm}$ dietary level, $60 \%$ of the mice died within 3 weeks on study; at the 20,000 ppm dietary level all mice died within 1 week on study. All of these deaths were considered to be treatment related. Slightly decreased feed consumption was noted in both sexes at the $2500 \mathrm{ppm}$ and 5000 ppm dietary levels. At the $10,000 \mathrm{ppm}$ dietary level, decreased feed consumption was noted in females. Decreased mean body weights and mean body weight gains were noted in females at the $2500 \mathrm{ppm}$ dietary level, and in both sexes at the $5000 \mathrm{ppm}$ and $10,000 \mathrm{ppm}$ dietary levels. A slight but statistically significant increase in serum glutamic-pyruvic transaminase values was observed in males at the $5000 \mathrm{ppm}$ and $10,000 \mathrm{ppm}$ dietary levels; because there were no histopathological findings observed in the liver corresponding to these clinical changes it was concluded that these results were not treatment related. RBC CHE activity was reduced in females from the $10,000 \mathrm{ppm}$ group, but not in males at the same dose.

Slight to moderate decreases in spleen weight were observed in females at the 1000,5000 and $10,000 \mathrm{ppm}$ dietary levels. There were also sporadic changes in other organ weights (brain, pituitary, gonads, uterus, liver, adrenals, kidneys, heart). Since none of these findings exhibited a dose-related response and were not accompanied by corresponding histopathology changes, these findings were not considered to be treatmentrelated. Except for an increase in brown pigmentation of the splenic medulla, there were no treatment related histopathological changes observed. The NOEL for this study was considered to be $1000 \mathrm{ppm}(123.3 \mathrm{mg} / \mathrm{kg} /$ day) for males and $2500 \mathrm{ppm}(278.1 \mathrm{mg} / \mathrm{kg} /$ day $)$ for females.

(Nihon University of Veterinary Medicine and Zootechnology, 1971)

\section{Ninety-Day Feeding Study in CD-1 Mice}

Butachlor was administered in the diet to groups of 30 male and female CD-1 mice each, at concentrations of 0 , 1000,3000 , and $6000 \mathrm{ppm}$ for at least 91 days. The animals were housed individually in suspended stainless steel cages. The animals at the $6000 \mathrm{ppm}$ dietary level exhibited decreased body weights, hematological changes, decreased blood urea nitrogen levels, decreased brain cholinesterase activity, organ weight changes (brain, liver, and ovaries) and histopathological evidence of liver and kidney damage. Decreased body weights, and increased blood urea nitrogen, platelet levels, and liver weights were noted in the animals at $3000 \mathrm{ppm}$ dietary level. The animals from the $1000 \mathrm{ppm}$ group exhibited increased liver weights, but no corresponding histopathological changes and is therefore, considered to be equivocal evidence of toxicity. The NOAEL for this study was considered to be $1000 \mathrm{ppm}(213.9 \mathrm{mg} / \mathrm{kg} / \mathrm{day}$ for males and $247.9 \mathrm{mg} / \mathrm{kg} /$ day for females).

(Bio/dynamics, Inc., 1980)

\section{Twenty-one Day Dermal Toxicity Study in Rabbits}

Butachlor was administered dermally to groups of 10 male and female New Zealand White rabbits each, 5 days/week for 3 consecutive weeks at dose levels of 0 , 100,500 and $2500 \mathrm{mg} / \mathrm{kg} / \mathrm{day}$. The animals were housed individually in suspended stainless steel cages. The only significant finding was an increase in glucose values in the females at the $2500 \mathrm{mg} / \mathrm{kg}$ dose level. These changes in glucose were not considered biologically relevant or an indication of toxicity. Butachlor produced no other systemic, clinical chemistry or pathological changes. Local skin changes consisting of mild dermatitis were observed at lower dose levels while severe effects were seen at $2500 \mathrm{mg} / \mathrm{kg} / \mathrm{day}$, the highest level tested. The NOEL for systemic toxicity from repeated dermal application of butachlor was considered to be $2500 \mathrm{mg} / \mathrm{kg} /$ day.

(International Research and Development Corporation, 1982)

\section{CHRONIC TOXICITY AND ONCOGENICITY STUDIES}

\section{Twelve-Month Oral Study in Dogs}

Butachlor was administered orally via gelatin capsules to groups of 6 male and female beagle dogs each, at dose levels of $0,1,5$, and $25 \mathrm{mg} / \mathrm{kg} /$ day for 12 months. The animals were housed individually in stainless steel cages. No treatment-related effects of butachlor were observed on survival, body weights, hematology, urinalysis or gross pathology. Target organ effects (alkaline phosphatase, organ weight increases and histopathology findings) were observed in the liver and pancreas in dogs administered $25 \mathrm{mg} / \mathrm{kg} /$ day butachlor. The NOEL for this study was considered to be $5 \mathrm{mg} / \mathrm{kg} /$ day.

(Institute of Environmental Toxicology, 1987)

\section{Two-Year Chronic Toxicity/Oncogenicity Study in Fischer-344 Rats}

Butachlor was administered in the diet to groups of 90 male and female Fischer-344 (F-344) rats each, at concen- 
trations of 10,100 and $1000 \mathrm{ppm}$ for 24 months. Treatment-related signs of toxicity at the $1000 \mathrm{ppm}$ dietary level included an approx. 9\% reduction in body weight gain, slight increases in liver, kidney, adrenal and thyroid weights, plasma chemistry and histopathological evidence of liver, kidney, bladder, and ocular toxicity. A maximum-tolerated dose (MTD) was achieved at the $1000 \mathrm{ppm}$ dietary level. Butachlor was not oncogenic in the F-344 rat. The chronic NOEL in F-344 rats was considered to be $100 \mathrm{ppm}(3.6 \mathrm{mg} / \mathrm{kg} / \mathrm{day}$ for males and $4.33 \mathrm{mg} / \mathrm{kg} / \mathrm{day}$ for females).

(Institute of Environmental Toxicology, 1990)

\section{Two-Year Chronic Toxicity/Oncogenicity Studies in Sprague-Dawley Rats}

(1) Butachlor was administered in the diet to groups of 80 male and female Sprague-Dawley (S-D) rats each, at concentrations of $0,100,1000$ and $3000 \mathrm{ppm}$ for 26 months. The animals were housed individually in stainless steel cages. Increased deaths were observed in both sexes at the $1000 \mathrm{ppm}$ and $3000 \mathrm{ppm}$ dietary level during the last few months of the study. Reduced body weight was observed in males from the $1000 \mathrm{ppm}$ and $3000 \mathrm{ppm}$ dietary levels and in females from the $3000 \mathrm{ppm}$ dietary level. Food consumption was increased at these same dietary levels. Cholesterol levels were increased in males treated at the $3000 \mathrm{ppm}$ dietary level throughout the study and in males at the $1000 \mathrm{ppm}$ dietary level during the latter portion of the study. No other treatment-related biochemical alterations were observed. Increased urinary protein levels were seen in male and female rats at the $3000 \mathrm{ppm}$ dietary level and were considered to be treatment-related.

At sacrifice (interim and final) increases in liver, kidney, and thyroid weights and decreases in adrenal and spleen weights were observed only at the $3000 \mathrm{ppm}$ dietary level, however most of these changes were not statistically significant. Neoplastic changes were observed in the glandular stomach, nasal mucosa and thyroid gland, but only at very high toxic dose levels (i.e. $>1000$ ppm). Other chronic, non-neoplastic changes were hepatocellular swelling and chronic nephropathy observed in animals from all treated levels. A NOEL for neoplasms was established at $100 \mathrm{ppm}$. A definitive NOEL for non-oncogenic effects could not be established for this study.

(Bio/dynamics, Inc./Institute of Environmental Toxicology, 1983)

(2) A second chronic study was conducted with S-D rats to follow up on effects observed in the previous study and to establish a definitive NOEL for non-oncogenic effects. Butachlor was administered to groups of 80 male and female rats each, in the diet at concentrations of $0,5,20$, and $100 \mathrm{ppm}$ for 24 months. The animals were housed individually in suspended stainless steel cages.
The outcome of this second chronic rat study resulted in no observable adverse chronic effects in rats treated with butachlor at levels of $100 \mathrm{ppm}$ for 24 months. Specifically, there was no increase in the incidence, time of onset, or severity of kidney or liver pathology observed between untreated control rats and rats given $100 \mathrm{ppm}$ butachlor. No evidence of other chronic toxicity or oncogenicity related to butachlor treatment was observed. It was concluded that $100 \mathrm{ppm}$ produced no butachlor-related toxicity and was a definitive NOEL in this study $(4.9 \mathrm{mg} / \mathrm{kg} / \mathrm{day}$ for males and $6.1 \mathrm{mg} / \mathrm{kg} /$ day for females).

(Bio/dynamics, Inc./Institute of Environmental Toxicology, 1988)

(3) To determine the absolute NOEL for chronic toxicity in S-D rats, the effects observed in liver and kidney in two chronic studies were reviewed. The hepatocellular swelling observed in the first study at 100 ppm was not considered to have been related to treatment since it was not repeated in the second study and the increased incidence in treated groups from the first study did not vary in response to dose. In fact, the lowest dose group in males from the first study had the highest incidence of this lesion, and the highest dose in females had the lowest incidence among the treated groups. Therefore these changes were interpreted to have been spontaneous and not related to treatment.

An apparent increase in chronic nephropathy was observed in all treatment groups in the first study, however there was no increase in severity with respect to controls. In a repeat study there was no evidence of increased chronic nephropathy in any treatment group. The NOEL for butachlor chronic toxicity in S-D rats was considered to be $20 \mathrm{ppm}(1.0 \mathrm{mg} / \mathrm{kg} /$ day for males and 1 . $2 \mathrm{mg} / \mathrm{kg} /$ day for females).

\section{Twenty-Four-Month Oncogenicity Study in CD-1 Mice}

Butachlor was administered to groups of 100 male and female CD-1 mice each, in the diet at concentrations of 0 , 50,500 , and 2000 ppm for 24 months. The animals were housed individually in suspended stainless steel cages. No effects on survival were observed. Mean body weight was decreased in both sexes at the $2000 \mathrm{ppm}$ dietary level and males at the $500 \mathrm{ppm}$ dietary level. Mean food consumption was increased at the $2000 \mathrm{ppm}$ dietary level relative to control. Serum alkaline phosphatase, glutamic oxaloacetic transaminase and glutamic-pyruvic transaminase values observed in females at the $2000 \mathrm{ppm}$ dietary level were statistically greater than control values. After 54 weeks of treatment, elevated total cholesterol values were observed in both sexes at the $2000 \mathrm{ppm}$ dietary level. Organ weight changes (decreased brain, increased liver and kidney) were observed in animals at the 500 and $2000 \mathrm{ppm}$ 
dietary levels.

Evidence of microcytic anemia was evident in both sexes at the $2000 \mathrm{ppm}$ dietary level. While decreased hematologic parameters were noted clinically, no corresponding effect on tissues capable of hemopoietic element production was observed macroscopically. At week 53, an increased incidence of retinochoroidal degeneration was noted in males from the treated groups, but this effect did not persist at subsequent evaluation intervals. At week 104, the incidence of cataracts was increased in animals from the 500 and $2000 \mathrm{ppm}$ dietary levels. The cataracts appeared to be similar pathologically to spontaneously occurring lesions and as is often seen at similar or even higher incidences in aged mice than those reported in this study.

Necropsy findings in animals were limited to the kidneys and lungs and correlated with the histopathologic findings reported below. Microscopic examination revealed effects in the kidneys (nephrosis), eyes (cataracts), gallbladder (hyperplasia in high dose females only), and lung (alveolar/bronchiolar epithelial hyperplasia; increased macrophages) of both sexes at the 500 ppm and 2000 ppm dietary levels. No effects were observed in the gastrointestinal tract or the nasal region. There was no statistically significant increase in either pulmonary adenomas or carcinomas in mice at the terminal sacrifice at any dose level. The small increase in the number of multiple adenomas/carcinomas observed in males from all 3 treatment groups can be attributed to an unexpectedly lower incidence found in the control male group, when compared to historical control values with this strain of mouse at the testing laboratory. The NOEL for this study is considered to be $50 \mathrm{ppm}$ ( 7.13 $\mathrm{mg} / \mathrm{kg} /$ day for males and $8.56 \mathrm{mg} / \mathrm{kg} /$ day for females). (Hazleton Laboratories/Institute of Environmental Toxicology, 1985)

\section{EVALUATION OF THE ONCOGENIC POTENTIAL OF BUTACHLOR}

As noted above, neoplastic responses attributable to butachlor administration were observed in the stomach, thyroid, and nasal tissue of rats. A significant increase in stomach tumors was restricted to the female rat at the highest dose tested (i.e. $3000 \mathrm{ppm}$ ). The incidence of thyroid and nasal tumors increased significantly in the females from the $3000 \mathrm{ppm}$ and $1000 \mathrm{ppm}$ groups but in males at $3000 \mathrm{ppm}$ only. The highest dose, $3000 \mathrm{ppm}$ exceeded the MTD as evidenced by excessive body weight loss $(>30 \%)$, hepatocellular necrosis, and decreased survival. The MTD was shown to be $1000 \mathrm{ppm}$. The production of tumors only under these extreme conditions of exposure in rats is of doubtful relevance for humans. Also, a weight-of-evidence evaluation of data obtained from extensive mutagenicity testing reveals that butachlor has no significant genotoxic activity in mam- malian systems. These data indicate that the tumors observed in the rat arise through non-genotoxic, threshold-sensitive mechanisms. To better understand the mechanisms involved in the production of these rodent tumors and their relevance to humans, a series of additional mechanistic investigations were undertaken with butachlor, as well as with alachlor, a close structural analog of butachlor which produces the same neoplastic response. These additional studies have been communicated elsewhere, ${ }^{3)}$ and the results are summarized below.

\section{Rat Nasal Tumors}

Previous studies have demonstrated significant species differences in the metabolism and pharmacokinetics of alachlor and have provided a mechanistic basis for the rat-specific production of nasal tumors. Butachlor is metabolized in a similar manner to alachlor. Additional studies conducted with butachlor have further demonstrated that a common mechanism of action is operative for the formation of rat nasal tumors with butachlor and alachlor. Alachlor and butachlor are metabolized by common metabolic processes leading to the formation in rat nasal tissue of the quinoneimine metabolite of diethylaniline (DEIQ). This metabolite has been shown to localize and accumulate selectively in rat nasal tissue but not in the nasal tissues of other species. $^{4)}$ This metabolite forms protein adducts, ${ }^{5)}$ which leads to cytotoxicity, prolonged cell proliferation and the eventual development of the predominantly benign, microscopic nasal tumors observed. Increased cell proliferation is considered to be a prerequisite for nasal tumor development, and its induction is thresholdsensitive, i.e., there is a dose below which cell proliferation and the ensuing tumor formation do not occur.

Critical differences in enterohepatic circulation and target tissue metabolism result in greater formation of DEIQ in the rat nasal mucosa as compared to other species. Rat nasal tissue contains high levels of enzymes which metabolize alachlor or butachlor to 4-amino-3, 5-diethylphenol (DEA-phenol), the precursor to DEIQ. For example, the ability of rat nasal tissue to convert the secondary sulfide metabolite of alachlor to 2,6-DEAphenol, the proximate metabolite of DEIQ, is more than 30 times greater than that of monkeys ${ }^{6)}$ and 751 times greater than that of human nasal tissue. ${ }^{7)}$ Species differences are even larger when the relative enzymatic rate of the initial metabolic step (alachlor conjugation to glutathione) is included in the overall rate of DEAphenol formation from alachlor. When this is done, the overall ability of rats to convert alachlor to DEA-phenol is 3000 - and 22,000-fold higher than that of humans when the initial glutathione conjugation occurs in the liver or nose, respectively. ${ }^{7}$ ) These data indicate that the potential for the formation of the reactive DEIQ metabolite in human nasal tissue is negligible and demonstrate that 
with respect to alachlor as well as to butachlor, the rat is not an appropriate model for the assessment of nasal oncogenic hazard to humans.

\section{Rat Stomach Tumors}

An extensive research program was conducted to elucidate the mechanisms through which butachlor induced stomach tumors in rats. A stomach tumor initiationpromotion study was conducted with butachlor as part of this research program. ${ }^{8)}$ Butachlor had no activity as an initiator, but did promote tumor formation following treatment with a known initiator. Thus, the results from this study produced direct experimental evidence indicating a non-genotoxic mode of action for stomach tumorigenicity.

Mechanistic studies with butachlor have shown that high dose exposure leads to mucosal atrophy with an accompanying profound loss of parietal cells as the initial lesion., ${ }^{910)}$ The resulting gastric hypochlorhydria and increased $\mathrm{pH}$ induce a compensatory production of gastrin. Together, the progressive mucosal atrophy and excessive gastrin secretion drive a proliferative response which culminates in tumor formation. Butachlor did not produce mucosal atrophy at a lower, non-oncogenic dose level. The results of these mechanistic investigations provide strong evidence that butachlor produces stomach tumors in rats through a non-genotoxic, threshold-based mechanism.

This indirect mechanism of chloroacetanilide-induced stomach tumors does not present a human risk, since the conditions driving the requisite threshold-sensitive events are operative only in rats chronically exposed to very high dose levels. The prolonged exposure to excessively toxic doses required for tumorigenesis in rats could not occur in humans. Even if such exposure did occur, a study with rhesus monkeys showed that the key preneoplastic events (mucosal atrophy) do not occur in primates even at a dose that is twice that required to produce stomach tumors in rodents. Thus, there is compelling data supporting the conclusion that the stomach tumors are of no relevance to humans.

\section{Rat Thyroid Tumors}

Results from mechanistic work have shown that high dose butachlor exposure results in increased thyroid hormone clearance via induction of hepatic UDPGT activity, thereby causing a long-term, compensatory increase in circulating TSH levels. ${ }^{11)}$ It is widely recognized that such prolonged stimulation of the thyroid gland via elevated TSH secretion leads to follicular cell hyperplasia and neoplasia in experimental animals. ${ }^{12-14)}$ This hormone-mediated mechanism of carcinogenesis is considered to be a threshold phenomenon to which rats are particularly susceptible. The results with butachlor provide strong evidence that this non-genotoxic mecha- nism is operative in the production of butachlor-induced thyroid tumors in rats.

\section{GENOTOXICITY STUDIES}

The genotoxic potential of butachlor has been evaluated in numerous assay systems using a variety of species, metabolic activation conditions and endpoints. These assays tested Monsanto-produced butachlor in wellvalidated systems using established testing guidelines according to Good Laboratory Practice standards. Butachlor produced no evidence of a mutagenic response in the $E$. coli wp2 reverse mutation assay, but gave weak and inconsistent positive responses in the Ames/Salmonella reverse mutation assay. Increased revertant colonies caused by high doses of butachlor $(0.5$ to $10 \mathrm{mg}$ / plate) were less than 3 -fold above control values and occurred only in the TA-100 strain of Salmonella. In contrast, when tested in cultured Chinese hamster ovary (CHO) cells, no evidence of mutagenic activity was detected in the hypoxanthine-guanine phosphoribosyl transferase (HGPRT) forward gene mutation assay. The result of a $\mathrm{CHO}$ in vitro cytogenetics assay was also negative for clastogenic effects. Four in vivo mammalian tests have been conducted with butachlor. A bone marrow cytogenetics study with S-D rats at intraperitoneal (i.p.) dose levels of 75, 250 and $750 \mathrm{mg} /$ $\mathrm{kg}$, and a micronucleus test with Swiss-Webster mice at i.p. dose levels of 250,500 and $1000 \mathrm{mg} / \mathrm{kg} /$ day both revealed signs of general toxicity, but no evidence of adverse chromosomal effects. Exposure of CD-1 male mice to butachlor for 7 weeks at dietary concentrations of 100,1000 and $5000 \mathrm{ppm}$ revealed significant body weight depression, but no evidence of dominant lethal effects in male germ cells. An in vivo/in vitro DNA repair assay with F-344 rats at oral dose levels of 50, 200 and 1000 $\mathrm{mg} / \mathrm{kg}$ showed no increase in hepatocyte unscheduled DNA synthesis.

The weight of evidence supports the conclusion that butachlor does not have significant genotoxic potential in mammals. This conclusion is supported by an analysis of the butachlor genotoxicity data using a scoring system developed by the International Commission for Protection against Environmental Carcinogens and Mutagens. ${ }^{15,16)}$ This system generates an overall score using data from multiple test systems incorporating various weight of evidence considerations (e.g. doses used, species tested, in vitro vs. in vivo). The score of -12 for butachlor clearly positions it well in the non-genotoxic range of the evaluation system and provides objective confirmation of the conclusions from careful expert evaluation that butachlor does not have general genotoxic potential. Furthermore, the butachlor genotoxicity results support the conclusion that the rat-specific oncogenic responses do not result from genotoxicity but 
rather from butachlor's effects on non-genotoxic processes.

\section{REPRODUCTION AND DEVELOPMENTAL TOXICITY STUDIES}

\section{Two-Generation Reproduction Study in Rats}

Groups of 25 male and female Sprague-Dawley rats each, were fed butachlor in the diet at concentrations of $0,100,1000$, and $3000 \mathrm{ppm}$. Treatment began 10 weeks prior to the first mating to insure that a complete spermatogenic maturation cycle had occurred during butachlor treatment and continued throughout mating, pregnancy, and lactation periods for 2 successive generations. Each parental generation was mated to produce two litters per generation. Offspring from the second litters were selected to be parents for the subsequent generation. All animals were given a gross necropsy. Mating and fertility indices, as well as offspring weight/survival at birth and throughout lactation was evaluated for all litters. Histopathological evaluations were conducted on both sexes in the control and $3000 \mathrm{ppm}$ dietary level of parents from both generations as well as 6 male and female pups from the second litter of the second generation $\left(\mathrm{F}_{2} \mathrm{~b}\right)$. No adverse effects were observed on any reproductive parameter in any generation. Reductions in pup weights occurred at the $1000 \mathrm{ppm}$ and $3000 \mathrm{ppm}$ dietary levels during lactation but maternal and/or parental toxicity was also observed at these dose levels. The NOEL for reproductive toxicity in rats was considered to be $3000 \mathrm{ppm}(198.10-283.33 \mathrm{mg} / \mathrm{kg} /$ day for males and $245.65-319.73 \mathrm{mg} / \mathrm{kg} /$ day for females). The NOEL for general toxicity in parents and pups was considered to be $100 \mathrm{ppm}(6.74-8.13 \mathrm{mg} / \mathrm{kg} / \mathrm{day}$ for males and $8.40-9.58 \mathrm{mg} / \mathrm{kg} / \mathrm{day}$ for female).

(Bio/dynamics, Inc., 1984)

\section{Developmental Toxicity Study in Rats}

Butachlor was administered by gavage to 3 groups of 25 mated C-D female rats at dosages of 49,147 , and 490 $\mathrm{mg} / \mathrm{kg} /$ day on days 6 through 19 of gestation. An additional 25 mated females received distilled water and served as controls. On gestation day 20 , fetuses were examined externally, weighed, and processed for skeletal and soft-tissue examinations. Maternal toxicity occurred in the high dose group as evidenced by a decrease in maternal body weight. No butachlor-related effects were observed on total implantations, post-implantation loss, viable fetuses or fetal sex distribution at any dosage level. No effects considered related to butachlor exposure were seen following external, soft-tissue or skeletal examination of fetuses from all 3 dose levels tested. The NOEL for maternal toxicity in the rat was considered to be $147 \mathrm{mg} / \mathrm{kg} /$ day. Butachlor did not induce a teratogenic effect in rats.

(International Research and Development Corp., 1980)

\section{Developmental Toxicity Study in Rabbits}

Three groups of 16 mated female Dutch belted rabbits were administered butachlor by oral gavage at dosages of 49,147 , and $245 \mathrm{mg} / \mathrm{kg} /$ day and an additional 16 mated females received distilled water and served as controls. All animals were dosed daily from gestation day 7 through 27. All surviving females were sacrificed on gestation day 28 and routine uterine examinations were performed. All fetuses were weighed and examined for external malformations. Each fetus was then examined internally by dissection and then stained for skeletal evaluation.

The administration of butachlor resulted in significant maternal toxicity at the $147 \mathrm{mg} / \mathrm{kg} /$ day and $245 \mathrm{mg} / \mathrm{kg} /$ day dose levels. In addition to treatment-related deaths and abortions, mean maternal body weight losses, increases in post-implantation loss and decreases in fetal body weights were observed. The NOEL for maternal toxicity in the rabbit was considered to be $49 \mathrm{mg} / \mathrm{kg} /$ day. Butachlor did not induce a teratogenic effect in rabbits. (International Research and Development Corporation, 1980)

\section{PHARMACOLOGY STUDIES}

Butachlor was administered intraperitoneally to groups of 5 male and female ICR mice each, at single doses of $0,125,215,350,600$, and $1000 \mathrm{mg} / \mathrm{kg}$. All animals given the highest dose level died within 4 to 24 hrs after administration. Animal awareness, motor activity and autonomic nervous system responses were suppressed at levels of $600 \mathrm{mg} / \mathrm{kg}$ or above. Male and female mice given butachlor at a dose of $1000 \mathrm{mg} / \mathrm{kg}$ exhibited abnormal signs of toxicity characterized by excitation of the central nervous system, writhing, exophthalmos, hypothermia, lacrimation and soft stool. Most of the signs observed in the $600 \mathrm{mg} / \mathrm{kg}$ group were diminished within $24 \mathrm{hrs}$ after administration. No signs of toxicity were observed in animals given butachlor at dose levels of $350 \mathrm{mg} / \mathrm{kg}$ or less.

After acute oral administration of butachlor to 3 male and 3 female albino rabbits at dose levels of 0,1000 , 2300 , and $5000 \mathrm{mg} / \mathrm{kg}$, no abnormalities were observed at any of the levels tested. Butachlor was administered intravenously to groups of 3 male rabbits at dose levels of 50 and $150 \mathrm{mg} / \mathrm{kg}$. In the $150 \mathrm{mg} / \mathrm{kg}$ group, respiration was increased, and transient decreases in blood pressure, heart rate and blood flow were observed after administration. No abnormality was observed in the $50 \mathrm{mg} / \mathrm{kg}$ group.

In further experiments to explore the effects on the autonomic nervous system, gastrointestinal tract, skeletal muscle, or blood, butachlor produced no significant effect. In conclusion, butachlor has little or no effect on standard physiological parameters and pharmacological end-points. The effects observed occurred primarily at 
acutely lethal dose levels. The high dose levels required to produce severe effects confirm that the acute toxicity of butachlor is relatively low.

(Nippon Experimental Medical Research Institute Co., Ltd., 1993)

\section{EPIDEMIOLOGY STUDIES}

Three epidemiology studies have been conducted on the manufacturing workers at the Monsanto Muscatine plant in Iowa motivated primarily by the findings from the available toxicology studies with alachlor in which ocular and oncogenic effects were observed in the LongEvans rat. The same types of tumors were also observed in the toxicology studies with butachlor in the SpragueDawley rat. The outcome of extensive research investigations has proven that the same mechanisms are operative for the formation of stomach, nasal and thyroid tumors in rats with these compounds. The history of the Muscatine plant indicates that there is a high correlation of alachlor and butachlor exposure among manufacturing workers, and therefore, the results from the alachlor epidemiology studies are also relevant for butachlor.

A group of the highest-exposed workers was examined for the presence of a specific eye abnormality, analogous to the initiating lesion in Long-Evans rats, called pigmentary dispersion syndrome (PDS). ${ }^{17)}$ None of the exposed workers had PDS, and prevalence rates for other eye abnormalities were similar in exposed and unexposed individuals. In another study, there was no indication of increased mortality rates from cancer or any other causes among workers with up to 25 years of followup. ${ }^{18)}$ Likewise, cancer incidence rates over a 24-year period were not elevated in the highest-exposed alachlor/ butachlor workers, nor were there any cases of tumors in the nose, stomach, or thyroid, the organs in which oncogenic effects were produced in rats. ${ }^{19)}$ These manufacturing workers had year-round exposure greatly exceeding agricultural exposure, which is limited to a two- or three week period of application. In fact, manufacturing exposure was estimated to exceed yearly agricultural exposure by a factor of 10,000 or more. ${ }^{19)}$ Potential dietary exposures are even lower than agricultural exposure. Therefore, the absence of eye effects or increased mortality and cancer rates in manufacturing workers serve as an important indicator of the low potential for adverse effects among the general population, who are exposed to extremely low levels of alachlor/butachlor if at all.

\section{CONCLUSIONS}

The results of tests in laboratory animals indicate that butachlor has low mammalian toxicity following acute oral, dermal, and inhalation exposure. Butachlor has some potential to produce allergic skin reactions following repeated or prolonged exposure. Subchronic and chronic exposure produces primarily liver and kidney toxicity for which large margins of safety exist. Butachlor is not genotoxic and does not interfere with normal reproductive and developmental processes. Butachlor is not oncogenic in the Fischer-344 rat and CD-1 mouse. Neoplastic lesions were observed in the Sprague-Dawley rat in the nasal turbinate mucosa, stomach glandular mucosa, and thyroid follicular epithelium. Significant increases in the stomach, thyroid and nasal tumors occurred only at or above the MTD dose which produced excessive toxicity.

A large body of data supports the conclusion that butachlor produces these tumors in rats through nongenotoxic mechanisms for which thresholds exist. The conditions driving the requisite threshold-sensitive preneoplastic events occur only in experimental studies employing doses at or above the MTD. Observed species differences in physiology and metabolism indicate that the rat is particularly susceptible to the induction of nasal, thyroid and stomach tumors following chronic exposure to this agent. Consequently, humans would be at significantly lower risk for development of these tumors. In fact, substantial margins of safety exist, as human exposure is several orders of magnitude below the doses producing tumors in rats. Therefore, it is concluded that the butachlor-induced tumors in rats are not relevant to humans under actual conditions of exposure. This conclusion is supported by the lack of mortality and tumors in manufacturing workers who have the highest exposure to butachlor.

In summary, an extensive health and safety database has been developed to support the registration of butachlor and MACHETE ${ }^{\circledR}$ products worldwide. A thorough evaluation of these data indicates that butachlor products are of generally low toxicity and present minimal opportunity for human exposure. When used in accordance with label directions, butachlor will not adversely affect human health.

Based on a review of the studies summarized above, the Japan Ministry of Health and Welfare (MHW) established an Acceptable Daily Intake (ADI) for butachlor of $0.01 \mathrm{mg} / \mathrm{kg} /$ day employing the NOEL from the chronic rat study of $1 \mathrm{mg} / \mathrm{kg} /$ day and a safety factor of 100 . This ADI supports the current withholding limits established by the Japan Environmental Agency (EA) of 0.1 ppm in rice.

\section{REFERENCES}

1) E. Buehler: Arch. Dermatol. 91, 171 (1965)

2) H. Ritz \& E. Buehler: "Current Concepts in Cutaneous Toxicity," ed. by V. Drill \& P. Lazar, Academic Press, New York, pp. 25-40, 1980

3) W. Heydens, A. Wilson, L. Kier, H. Lau, D. Thake \& M. Martens: Hum. Exp. Toxicol. 18, 363-391 (1999)

4) P. Feng, A. Wilson, R. McClanahan, J. Patanella \& S. 
Wratten: Drug Metab. Dispos. 18373 (1990)

5) A. Wilson, H. Lau, K. Asbury, D. Thake \& W. Heydens: Presented at International Congress of Toxicology-VII, Seattle, 1995

6) A. Li, K. Asbury, W. Hopkins, P. Feng \& A. Wilson: Drug Metab. Dispos. 20, 616 (1992)

7) A. Wilson, H. Lau, K. Asbury \& W. Heydens: Toxicologist 15, Abstract 1398 (1995)

8) A. Wilson, D. Branch, M. Shibata, D. Thake, T. Shirai \& A. Hagiwara: Presented at Annual Conference of International Federation of Societies of Toxicologic Pathologists, Tours, 1995

9) G. Hard, M. Iatropoulos, D. Thake, D. Wheeler, M. Tatematsu, A. Hagiwara, G. Williams \& A. Wilson: Exp. Toxic. Pathol. 47, 95 (1995)

10) D. Thake, M. Iatropoulos, G. Hard, K. Hotz, C. Wang, G. Williams \& A. Wilson: Exp. Toxic. Pathol. 47, 107 (1995)

11) D. Thake, K. Hotz, C. Reisch \& A. Wilson, "A Study of the Mechanism of Butachlor Induced Carcinogenicity in Female Sprague-Dawley Rats," Unpublished Monsanto Report, MSL-14017, 1995

12) R. Hill, L. Erdreich, O. Paynter, P. Roberts, S. Rosentahl \& C. Wilkinson: Fund. Appl. Toxicol. 12, 629 (1989)

13) G. Thomas \& E. Williams: Mutat. Res. 248, 357 (1991)

14) G. Zbinden: Arch. Toxicol. Suppl 12. 98 (1988)

15) D. Brusick, J. Ashby, F. de Serres, P. Lohman, T. Matsushima, B. Matter, M. Mendelsohn, D. Moore II, S. Nesnow \& M. Waters: Mutat. Res. 266, 1 (1992)

16) P. Lohman, M. Mendelsohn, D. Moore II, M. Waters, D. Brusick, J. Ashby \& W. Lohman: Mutat. Res. 266, 7 (1992)

17) B. Ireland, J. Acquavella, T. Farrell, M. Anne \& T. Fuhremann: J. Occup. Med. 36, 738 (1994)

18) J. Acquavella, S. Riordan, M. Anne, J. Collins, B. Ireland \& W. Heydens: Environ. Health Perspect. 104, 2 (1996)

19) J. Acquavella, B. Ireland, T. Leet, M. Anne, T. Farrell \& M. Martens: In Proceedings of the XII Joint CIGR, IAAMRH, IUFRO International Symposium: Health, Safety and Ergonomic Aspects in Use of Chemicals in Agriculture and Forestry, June, 1993, Kiev, Ukraine: Institute for Occupational Health, p.184, 1994

\section{要 約 \\ ブタクロールの毒性試験の概要}

米国モンサント・カンパニー

ブタクロールは, 米国モンサント・カンパニーが開発し た一年生イネ科雑草および一部の広葉雑草を対象とする稲 作用除草剂である. 動物実験の結果, 本剂の哺乳動物に対 する急性経口, 経皮, 吸入毒性はいずれも軽微で, 眼およ
び皮膚一次刺激性は低い.モルモットを用いた皮膚感作性 試験において陽性の反応が認められた。亜急性および慢性 毒性試験の結果, 主として肝藏および腎臓に検体投与によ る影響が認められたが,これらの影響には閾值が存在した。 ラットを用いた慢性毒性/発がん性併合試験において腺胃, 鼻部および甲状腺の腫瘍が認められたが, 腫瘍発生のメ力 ニズムに関する試験研究の結果，これらの腫瘍は閾値の存 在する非遺伝子傷害性の作用によって引き起こされている ことが解明されている.これらの腫瘍の発生に結びつく前 段階の症状には閾值があり，最大耐量以上の用量でブタク ロールを投与した動物実験においてのみ認められた.また, 鼻部の腫瘍の発生には, ラットにおいてのみ認められる種 特異的代謝が関与していた。このようにラットにおいて観 察された腫瘍をヒトに外挿することは妥当ではない.この 結論は, ブタクロールへの暴露量が最も高いと考えられる ブタクロールおよびアラクロール製造工場の労働者を対象 とした疫学調査の結果, 死亡率および腫瘍発症率の増加が 認められなかったことからも支持されている，本剤には， 哺乳動物生体内における遺伝毒性は認められず，正常な繁 殖や発生過程を阻害することもなかった。

ここに要約した毒性試験成績の評価に基づき，ラットに おける慢性毒性/発がん性併合試験における無毒性量 1 $\mathrm{mg} / \mathrm{kg} /$ 日および安全係数 100 を用い, $0.01 \mathrm{mg} / \mathrm{kg} /$ 日の ADI が設定されている.

ブタクロールは, マーシェット®粒剂として昭和 48 年 3 月登録を取得して以来, 水田用の雑草発生前土壤処理剂と して広く使用されている. 登録保留基準は, 米に $0.1 \mathrm{ppm}$ と 設定されている.

\section{Contacts}

Monsanto Company, 800 N. Lindbergh Blvd., St. Louis, MO 63167, USA

Regulatory Affairs Team, Agro-Science Division, Monsanto Japan Limited, Mita 43 Mori Bldg., 3-13-16, Mita, Minato-ku, Tokyo 108-0073, Japan

\section{問合せ}

日本モンサント株式会社アグロサイエンス事業部テクノロ ジー本部規制・環境部

テ108-0073 東京都港区三田 3-13-16 三田 43 森ビル 